\title{
US laws that protect tobacco users from employment discrimination
}

\author{
John Malouff, John Slade, Carrie Nielsen, Nicola Schutte, Erika Lawson
}

Nova College, Fort Lauderdale, Florida, USA

J Malouff

C Nielsen

N Schutte

\section{University of}

Medicine \& Dentistry

of New Jersey \&

St Peter's Medical

Center,

New Brunswick,

New Jersey, USA

J Slade

Muhlenberg College,

Allentown,

Pennsylvania, USA

E Lawson

Correspondence to:

John Malouff, Nova

College, 3301 College Ave, Fort Lauderdale, Florida 33314, USA

\begin{abstract}
Objective - To describe current US laws that protect smokers from employment discrimination.

Data sources - Laws of the states and the federal government.

Results - Federal law offers no employment protection to smokers. About half the states have smokers' employment rights laws. The laws vary with regard to (a) what employee actions are protected, (b) which employees they protect, (c) what employer conduct is prohibited, (d) what the legal consequences are of a violation, and (e) what the exceptions are. Every year more states enact smokers' rights laws. A recent trend is for states to allow more exceptions to the laws. Conclusions - Some smokers' rights laws are unnecessarily punitive; some are deceptive; and many, especially the older ones, fail to provide reasonable exceptions.

Tobacco Control 1993; 2: 132-138
\end{abstract}

\section{Introduction}

As of 1991 about $2 \%$ of US companies refused to hire smokers and about $17 \%$ had a formal

Table 1 State smokers' rights laws and what they prohibit employers from doing

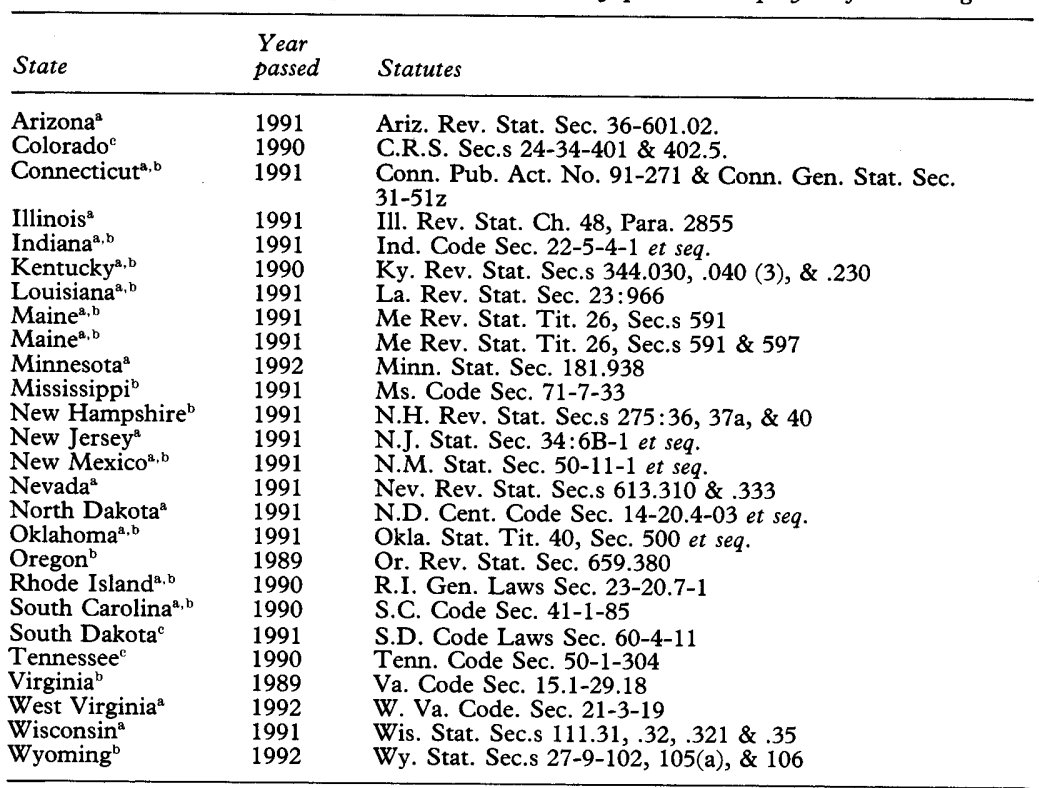

a Law bars any discrimination against or adverse employer effect on smoker

- Law bars requiring no smoking off-the-job

Law bars terminating employee for smoking off-the-job

preference for hiring non-smokers. ${ }^{1}$ Informal, personal preferences were also common among individuals who hired employees. ${ }^{2}$

Since 1989, 25 states have enacted laws (sometimes called "smokers' rights laws") that prohibit employment discrimination against tobacco users. Table 1 lists these states. Many other states have considered and rejected such laws. ${ }^{3}$

Tobacco interests and, to some extent, the American Civil Liberties Union, a civil rights group, have promoted these laws from coast to coast, arguing that it is a violation of the right to privacy for employers to tell employees what to do off the job. ${ }^{4}$

Why would anyone prefer to hire nonsmokers? The answer may differ from organisation to organisation and supervisor to supervisor. Some possible reasons include evidence that smokers as a group have more job accidents, suffer more work injuries, and create more disciplinary problems at work than do non-smokers; ${ }^{5}$ a desire of some companies to avoid worker compensation claims for lung damage that could be due to either smoking or an occupational hazard, such as fighting fires; $;^{6}$ a desire for physically fit employees, for jobs such as police officer and firefighter $;^{7}$ a desire to avoid the appearance of hypocrisy, when a smoker works in a job to prevent or treat dependence on nicotine or some other addictive substance $;^{8}$ a need to maintain a super-clean workplace free of even the tobacco on the breath of employees $;^{8}$ the higher cost of employer-subsidised life, health, disability, and worker compensation insurance when some employees are smokers $;^{9}$ the belief that smokers take more sick leave ${ }^{2}$ the fear that occupational toxins such as asbestos may interact with smoking (even if limited to offwork time) to increase risks among employees; and the desire of some religious organisations to hire employees who follow off-work the non-smoking tenets of the religion. Also, the US tradition has long been one of employment at will, meaning that employers can hire and fire whomever they like for whatever reason they want. ${ }^{10}$ For instance, employers might choose to hire employees who are relatives, who look or act a certain way, or who seem to desperately need a job. A major limitation on this employer freedom in modern times has been a series of federal and state civil rights laws that prohibit employment discrimination based on race, sex, ${ }^{11}$ age, ${ }^{12}$ and disability. ${ }^{13}$

Health and employer groups have been 
promoting arguments against the smokers' rights laws in legislatures across the country. ${ }^{4}$ A series of titanic lobbying struggles in legislatures, fought with political pressure, financial contributions, and arguments about policy issues, has left the US divided; as of late 1992, 25 states have smokers' rights laws, and 25 states and the District of Columbia do not.

The policy issues on both sides of the argument have been examined by several commentators, who, like the states, show a divided opinion, with some in favour of at least some version of the laws ${ }^{8,14-16}$ and some totally against. ${ }^{7,17}$

Rather than join the debate about whether smokers' rights laws should be enacted, we simply wish to describe the various versions of the state laws passed. In particular, we will examine (a) which employees the laws protect, (b) what employees actions are protected, (c) which employers are bound, (d) the legal consequences of a violation, (e) what the exceptions are, and (f) what trends have occurred over time. We will also take a brief look at other laws, most of which are intended to protect disabled individuals from employment discrimination, that might incidentally bar such discrimination against tobacco users.

\section{State laws}

No two of the 25 state smokers' rights laws are identical, but there are many similarities among them. All 25 prohibit employers from discriminating against employees who smoke off the job. None of the laws requires employers to allow smoking on the job or on the employer's premises.

\section{WHAT EMPLOYEE ACT IS PROTECTED?}

Most of the 25 states specifically protect smoking or use of tobacco off the job. Illinois, Minnesota and Nevada protect "lawful consumption" of a product off the job; Colorado, North Dakota, and Wisconsin protect any "lawful act" off the job; and Tennessee protects any use off the job of an "agricultural product" other than alcohol. Although it may be that Tennessee was experiencing a major problem with employment discrimination against kumquat eaters, it seems likely that this particular version of a smokers' rights bill was passed in order to mislead the public about the main purpose of the law and thereby reduce public opposition. The same could be said about the "lawful consumption" versions.

Practical problems, however, are more likely to occur with the "lawful act" versions. These laws, which were seemingly phrased so as to reduce political resistance, appear to protect not just smoking off the job, but also whistleblowing (ie, turning in one's own company for unlawful activities). We have no quarrel with that extension of the law. However, other lawful off-duty acts that an employer might object to may also be protected. For instance, could an employer sanction employees for working part-time for competitors? For in- ebriation in front of company clients at an offwork dinner engagement? For offensive public comments? Imagine a restaurant manager telling the media at a $\mathrm{Ku}$ Klux Klan rally, "I hate serving blacks". Although the existence of exceptions to the laws (discussed below) may prevent problems such as these, unpleasant surprises could be ahead for employers in these states.

Although all 25 laws protect smokers, only seven states expressly bar discrimination against employees based on their being nonsmokers. These states are Arizona, Kentucky, Louisiana, New Jersey, New Mexico, Oklahoma, and Wyoming. This provision might come into play in various cases, such as if a smoking employer wants to hire only smokers in order to have fellow smokers around, to reduce the chance that employees might push for a worksite smoking ban, or to avoid future litigation from non-smoking employees because of a smokey work environment.

WHO IS PROTECTED?

Twenty-two of the 25 states protect both employees and job applicants. Colorado, South Dakota, and Tennessee protect only employees. Usually the term "employee" is not defined.

\section{Federal employees}

One likely constitutionally required exception, not usually mentioned in the statutes, involves employees of the federal government. Because federal laws are supreme in the US, the individual states cannot restrict federal actions without the consent of the federal government. ${ }^{18}$

\section{Independent contractors}

The state laws do not bar organisations from hiring independent contractors who are nonsmokers. American law distinguishes between employees and independent contractors for various reasons. For instance, the negligence of an employee, but not an independent contractor, is imputed to the organisation that hires him or her. ${ }^{19}$

There are many factors that are considered in determining whether a person is an employee or independent contractor. In general, independent contractors (a) are more independent than employees in deciding how to do their work, (b) control their work premises, (c) can hire employees, (d) are paid by the job, (e) have the right to delegate, and (f) pay their own income tax withholding. ${ }^{20}$

A babysitter who comes to my home, follows my instructions, and is paid by the hour would probably be considered an employee. Someone who takes care of children of different parents in his or her own home and provides a set programme for them would likely be considered an independent contractor.

WHAT EMPLOYER CONDUCT IS PROHIBITED? Fourteen of the states bar employers from 
requiring no smoking off the job; 17 states, including some of those with the above rule, bar discrimination against or adverse effect on employees who smoke off the job; and three states bar only termination of employees for smoking off the job (see table 1).

Barring any adverse effect on employees who smoke off the job may make it impossible for employers to have a rule prohibiting employees from coming to work smelling of smoke. However, employers could accomplish the same thing by simply barring any offensive personal smell. More important, this "adverse effect" version of the law would seem to bar employers from providing separate but equally funded subsidised health, life and disability insurance for smokers, because separate treatment would leave the smokers paying much more for their share. This issue is discussed more fully below.

\section{WHAT ARE THE CONSEQUENCES OF VIOLATING THE LAW? \\ Damages}

Prohibited discrimination in all the states gives the employee the right to sue for damages. Some states state that explicitly, while in the others this right is implicit in making the discrimination "unlawful". These damages would include at least lost wages and benefits.

\section{Attorneys' fees}

Colorado, Minnesota, Nevada, New Mexico, North Dakota, Oregon, and Oklahoma give the winning party the right to attorneys' fees. Connecticut, Illinois, Indiana, New Jersey, and Rhode Island give only the employee or prospective employee this right, if he or she prevails. A unilateral right to attorneys' fees is very valuable to employees in light of the possibility that these fees will be greater than the damages awarded for lost wages.

\section{Duty to mitigate damages}

In order to recover damages for lost wages, employees who are discriminated against must make reasonable efforts to obtain another job, and their earnings elsewhere will reduce the damages they are awarded. Colorado, New Mexico, and South Dakota mention this expressly, but probably all the other states would apply this duty as a matter of common (courtmade) law. ${ }^{21}$

\section{Injunctions}

Connecticut, Indiana, Nevada, North Dakota, New Jersey, Oregon, and Rhode Island specifically allow courts to give injunctive relief, which might include ordering the employer to hire the person who is suing. Colorado, Minnesota, and Oklahoma exclude injunctive relief. In the other states, courts could issue such orders even without specific mention in the smokers' rights act. The decision whether or not to issue an injunction is usually based on a myriad of considerations, including whether financial compensation would suffice and whether the injunction could, as a practical matter, control day-to-day interactions between employee and employer. ${ }^{22}$ Courts are very reluctant to order a company to hire or retain a certain individual, ${ }^{23}$ but they might be willing to order a change in a hiring policy.

\section{Penalties}

Seven states mention penalties in their laws. Rhode Island allows courts to award triple damages to a prevailing employee. Oregon expressly allows an award of punitive damages against the employer. Under common law principles, courts in other states might also award punitive damages for a malicious violation of the law. ${ }^{24} \mathrm{New}$ Jersey allows courts to apply a civil penalty of up to $\$ 5000$, and Louisiana allows a fine of up to $\$ 500$. Arizona and Illinois make violation of the law a petty offence, and New Hampshire makes it a misdemeanour.

Some states, such as Kentucky, Oregon, and Wyoming, expressly combine their protection of smokers with employment protection relating to race, gender, and other characteristics and allow civil rights commissions to take actions against employers that discriminate.

WHAT ARE THE EXCEPTIONS?

Nineteen of the 25 state laws have at least one exception, and some states have several.

\section{Bona fide occupational requirement}

The most common exception applies when a "bona fide occupational requirement" exists for the employer to discriminate in a certain way with regard to off-the-job smoking. Colorado, New Mexico, Minnesota, Oklahoma, Oregon, South Dakota, Wisconsin, and Wyoming allow this exception.

The wording is similar to an exception in the federal Age Discrimination in Employment Act ("bona fide occupational qualification reasonably necessary to the normal operation of the particular business"). Although bona fide merely means in good faith, ${ }^{25}$ courts have interpreted the federal phrase to mean that the employer must have an objective, factual, basis for the requirement. ${ }^{26}$

New Jersey dispensed with the lengthy, legalistic terms and created a similar exception whenever the preferential treatment of nonsmokers "has a rational basis".

We believe that these general exceptions would properly be interpreted to include the various more specific exceptions described below.

\section{Conflict of interest}

Colorado, Minnesota, South Dakota, and Wisconsin created an exception whenever necessary to avoid a conflict of interest or the appearance of a conflict of interest. New Mexico makes an exception for a conflict of interest policy "designed to protect the em- 
ployer's trade secrets, proprietary secrets... information or ... interests". It is not apparent to us how an anti-smoking policy could protect trade secrets, but the "proprietary interests" provision seems to make the exception as broad as that of the other "conflict" states.

This type of exception could apply when an organisation is involved in promoting nonsmoking (eg, the American Heart Association) or treating substance abuse, including not only nicotine dependence but also alcoholism and other drug problems. Addiction to nicotine is very common among people with other drug problems, and major elements of the therapeutic programme may be undermined when any treatment staff member uses tobacco.

Whether such an exception would apply to organisations that promote health in general (eg, a state health department) or treat various types of health problems (eg, a hospital) is a difficult issue that courts in each of these states may some day be required to decide.

\section{Insurance benefits}

Illinois, Minnesota, South Dakota, West Virginia, Wisconsin, and Wyoming allow employers to make distinctions between smokers and non-smokers with regard to insurance benefits. This provision reflects the lower premiums available to non-smoker groups for life, disability, and health insurance. Using the provision, an employer could provide, say, $\$ 200$ per month of the premium for each employee and let non-smokers pay $\$ 50$ and smokers $\$ 150$

Without this type of exception, employers might have to provide the same coverage to smokers and non-smokers. The employer could pay $\$ 250$ per month and ask all employees to pay $\$ 50$ or it could pay $\$ 200$ per month and ask all employees to pay $\$ 100$ per month. In essence, then, either the employer or the nonsmoking employees would subsidise, to some extent, the smoking of some employees.

Anti-smoking organisations

Connecticut, Illinois, Rhode Island, Wisconsin, and West Virginia exempt non-profit employers when one of their primary purposes is to discourage the use of tobacco or "lawful products" by the public. Such organisations would include cancer, lung and heart associations and anti-smoking pressure groups.

\section{Impaired job performance}

Illinois, Minnesota, Nevada, South Dakota, and Wisconsin allow employers to ban the use of tobacco when it impairs the job performance of the employees or the safety of employees. This provision could apply to employees who (a) need to be physically fit, such as athletes, police officers, and fire-fighters; (b) work to prevent or treat nicotine dependence; (c) work in a super-clean environment where their smokey breath might harm a product or process; or (d) do work such as driving a bus or assisting with surgery, where nicotine withdrawal might increase the risk that they will make an error that causes harm to someone.

\section{Fire-fighters and police}

South Dakota, Virginia, and Wisconsin specifically exempt fire-fighters. Connecticut exempts fire-fighters and police officers when there is a collective bargaining agreement that allows a preference for non-smokers. Many fire-fighters develop lung diseases that are commonly caused by tobacco smoke but that can also be caused by the smoke of fires. In order to give the fire-fighters the benefit of the doubt, some states automatically grant workers' compensation benefits to any firefighter who develops lung disease. ${ }^{6}$ One way to reduce substantially the number of such claims is to ban smoking by the fire-fighters. Connecticut may exempt police officers because of their need to be physically fit.

\section{Religious organisations}

Wisconsin exempts religious organisations if smoking violates a tenet of the religion. One possible reason for this exception is to allow religions to require behaviour off the job that meets the moral standards of the religion. Apparently going beyond this reasoning, Colorado, Indiana, and Wyoming exempt all religious organisations.

\section{Collective bargaining}

Oklahoma and Oregon exempt employers who have collective bargaining agreements that allow a preference for non-smokers. The idea here appears to be that the state should not interfere with fairly negotiated arrangements between workers and employers.

\section{State or private employers}

Connecticut and Maine exempt the state from application of their laws. Arizona and Virginia apply their laws only to the state. It is hard to identify any major policy that would support either approach with regard to smokers' rights.

\section{Small organisations}

Nevada exempts employers of less than 15 individuals; Kentucky employers of less than eight, and Wyoming employers of less than two. The goal here is to allow individuals who employ only a few persons and who work with them closely to have wide latitude in hiring. This type of exemption figures in federal employment rights acts too, such as the one that bars discrimination on the basis of immutable characteristics such as sex and race. ${ }^{11}$

\section{Domestic help}

Colorado and New Hampshire exempt domestic help from the statutes. One justification for this in addition to that mentioned above might be the desire of parents that child 
caretakers set a good model even when off work.

\section{Agricultural and temporary workers}

New Hampshire exempts agricultural workers and temporary workers. The exemption for agricultural workers may relate to the possible interactions between occupational exposures (eg, to pesticides) and smoking (even if limited to off-the-job time). The reason for the exemption for temporary workers is unclear.

\section{Non-profit-making associations}

Nevada, New Hampshire, and Wisconsin also exempt certain non-profit-making associations, perhaps on the theory that they should be allowed more freedom to hire whom they want.

\section{Employees in drug treatment}

Minnesota exempts employees when their use of a "lawful consumable product" amounts to failure to comply with chemical dependency treatment. This unusual provision probably reflects the expectation that alcohol abusers will claim the protection of the law.

WHAT TRENDS ARE OCCURRING?

Two trends are apparent in smokers' rights laws. First, the number of states passing these laws has grown rapidly since 1989 . Even as this article is being written more states are enacting smokers' rights laws (and some are rejecting them)..$^{3}$

Second, the laws enacted in the past year have had more exceptions to their application than the laws passed in the preceding three years. This trend may be the result of additional time to contemplate the impact of the laws or the result of the sort of political compromising needed to pass the laws in states that were not inclined toward the earlier tobacco industry lobbying efforts.

\section{Federal laws}

Rothstein $^{14}$ has argued that various federal laws and rights may protect smokers from job discrimination, but no court has ever accepted any of these arguments. In the few relevant decisions available, courts rejected claims based on privacy and other rights and found against the smokers. ${ }^{27-30}$

Rothstein mentioned section 1140 of the Employee Retirement Income Security Act (ERISA), ${ }^{31}$ which bars certain large employers from discriminating against or firing an employee "for the purpose of interfering with the attainment" of health insurance benefits to which he or she may become entitled. $\mathrm{He}$ argues that these employers therefore cannot lawfully terminate an employee for the purpose of saving money on health benefits. However, in McGann v. $\mathrm{H} \& \mathrm{H}$ Music, ${ }^{32}$ the US Fifth Circuit Court of Appeals reached a contrary decision in a case which the US Supreme
Court declined to review. The court held that companies covered by ERISA may "discriminate" between employee groups with regard to health benefits as long as they do not intend to discriminate against specific individuals. Hence, the court allowed a company to restrict severely health benefits for employees with AIDS as opposed to employees with other disorders. By analogy, companies could require smoking employees to pay more than non-smoking employees for health insurance partly subsidised by the employer.

It has come to our attention that some corporate attorneys believe that state smokers' rights laws do not apply to companies covered by the federal ERISA. Although federal laws are supreme over inconsistent state laws, ${ }^{18}$ we see nothing in state laws inconsistent with ERISA, so we believe that the state laws do apply.

$\mathrm{Goh}^{33}$ has argued that the recently passed Americans with Disabilities Act ${ }^{13}$ (ADA) bars employment discrimination against smokers. The wording of the ADA is vague enough to allow serious argument about whether smokers' employment rights are protected by the act.

The ADA bars employment discrimination against disabled individuals. The act defines "disability with respect to an individual" as

"(A) a physical or mental disability that substantially limits one or more of the major life activities of such individual; (B) a record of such impairment; or (C) being regarded as having such an impairment".

Dependency on nicotine is listed as a mental disorder in the American Psychiatric Association's Diagnostic and Statistical Manual IIIR. ${ }^{34}$ However, having a disorder does not necessarily mean that a person has a disability or is limited substantially in one or more major life activities.

An argument can be made that being a smoker may limit one or more important life activities. Certainly aerobic activities, involving work or play, may be limited, but to many adults the limitation is not substantial and the specific activities limited are not usually major life ones. Also, social opportunities may be restricted because of the preference of many individuals for non-smokers with regard to dating and marriage. ${ }^{35}$ While these activities are major ones for many people, it would be difficult to say in an individual case that the limitation is substantial.

While it may be possible to interpret the statute loosely enough to apply it to individuals because they are smokers, the statute is, at best, ambiguous on this issue. When a federal statute is ambiguous, Congressional intent controls interpretation of it. ${ }^{36}$

Three reasons convince us that Congress did not intend to include smokers in this definition. First, section 12101(a) (1) of the act states as a finding that " 43000000 Americans have one or more physical or mental disabilities..." When the law was passed in 1989 there were about 50000000 smokers alone in the US. ${ }^{37}$ Hence, Congress did not consider smokers, as a group, to be disabled. 
Second, the act has detailed rules applicable to alcoholism as a disability, and we believe that Congress would have also adopted a special set of rules with regard to smoking if it had wanted to include it as a disability.

Third, few if any Americans speak or write about smokers as being physically or mentally disabled. We think that Congress likewise did not mean to include smokers when it used the expression "physical or mental disability".

The tobacco industry has ignored the Disabilities Act since it was passed and has pushed ahead with getting state laws passed to protect smokers from employment discrimination. The industry must indeed be reluctant to press the argument that being a smoker makes a person mentally or physically disabled. Many individual smokers probably share this reluctance, so it may be some time before someone seeks a court determination of whether the ADA protects smoking by employees.

The ADA contains various exceptions with regard to factors such as bona fide reasons for preferences for non-disabled employees. As we do not believe the act applies to smokers, we will not discuss these.

\section{State laws that protect the disabled from employment discrimination}

Many states have laws that bar employment discrimination against disabled individuals. Depending on the wording and legislative intent, the laws might protect smokers from employment discrimination. A review of all these laws is beyond the scope of this paper, but it is worth noting that administrative orders have been issued by Human Rights agencies in Minnesota ${ }^{38}$ and New York ${ }^{39}$ to protect individuals from job discrimination based on their being smokers. These types of laws, as in Minnesota ${ }^{40}$ and New York, ${ }^{41}$ typically lack many of the exceptions created in laws specifically drafted to protect smokers.

\section{Conclusion}

Rather than argue about whether smokers' rights laws should be enacted, we set out to analyse the actual laws that have been passed. Our analysis leads to the following conclusions.

1. If a state decides to enact legislation to protect smokers from employment discrimination, it can do so without treating employers like criminals. We see no reason to create a punitive system such as the ones that exist in several states. We believe that employers who prefer to hire non-smokers usually have goodfaith reasons for their preferences and are acting in furtherance of the traditional US principle of employment at will. Hence, we suggest that states eschew criminal and civil penalties and not include provisions that allow prevailing employees but not employers to be awarded attorneys' fees. The federal acts that deal with employment discrimination are good models in this regard. ${ }^{11-13}$

2. The practice of passing smokers' rights laws without mentioning smoking or tobacco in them is an attempt to deceive the public about the main purpose of the law.

3. States may come to regret barring employers from terminating employees for any lawful off-the-job behaviour. This form of the law may lead to expensive litigation over what off-the-job behaviour is a bone fide employer concern.

4. Reasonable exceptions make sense for any law, as the federal government has recognised in creating exceptions to all its employment rights acts. It is noteworthy that some states think smokers deserve blanket protection against employment discrimination, while the federal government acknowledges reasons for exceptions to laws that bar preferences based on characteristics such as race, religion, and gender. ${ }^{11}$ Fortunately, recently enacted smokers' rights laws have included more exceptions than the laws passed earlier.

5. The rational-basis exception of New Jersey seems quite sensible because it allows exceptions that may not be obvious at the time the laws are passed, eg, the need of certain pharmaceutical companies to have super-clean work environments. We prefer this wording to that including "bona fide" because "rational basis" is easier to understand and more direct. Good faith is not the main issue; the reasonableness of the preference is.

6. A general exception makes many specific ones unnecessary, but to be sure it would be best for legislatures to specify the others. We favour exceptions for anti-smoking organisations, organisations that seek to prevent or treat nicotine dependence, fire-fighters, religious organisations that consider smoking against their tenets, employees whose performance is impaired by smoking, organisations with under 15 employees, the same as in the $\mathrm{ADA},{ }^{13}$ and exceptions with regard to insurance benefits.

7. The majority of states with a smokers' rights law illogically protect smoking off-thejob without also protecting non-smoking offthe-job. Why create rights for smokers with no equivalent rights for individuals who choose not to smoke?

8. Only state laws appear to bear employment discrimination against smokers. However, courts could conceivably conclude that the federal ADA, with its exceptions, protects smokers as a group.

9. Because state smokers' rights laws seem to be spreading across the nation in various versions, it is time to start collecting data on the effects of the different versions. How have the laws affected employer practices? Are employees aware of the laws? How many lawsuits are being filed based on the laws? What are the effects, if any, of the laws on employee smoking and job satisfaction? At present, we have no solid evidence with which to answer these questions.

1 Bureau of National Affairs. SHRM-BNA Survey No. 55 , Smoking in the Workplace: 1991. Washington, DC Smoking in the Workplace: 1991. Washin
Bureau of National Affairs, 29 August 1991.

2 Malouff J, Schutte N. The employment advantage of being a smoker. $\mathcal{f}$ Drug Educ 1990; 20: 329-36. 
3 Action on Smoking and Health. Smoking protection legislation. Washington, DC, 1992.

4 Scott J. Smokers' rights asserted under new job bias laws. Los Angeles Times, July 23 1991, Sec. A, p. 5.

5 Ryan J, Zwerling C, Endel J. Occupational risks associated with cigarette smoking: A prospective study. Am F Public Health 1992; 82: 29-32.

6 Thompson E. The constitutionality of an off-duty smoking ban for public employees: Should the state butt out? Vanderbilt Law Rev 1990; 43: 491-527.

7 Gambescia S, Godshall W. Smokers do not deserve special status. HR Focus 1991; 68: 11 .

8 Slade J. Protection from job bias for people who smoke. $f$ Subst Abuse Treat. In press.

9 Nelkin L. No butts about it: smokers must pay for their pleasure. Columbia $\mathcal{F}$ Environ Law 1987 (spring): 317-41.

10 DiSabatino M. Modern status of rule that employer may discharge at-will employee for any reason. Am Law Rev 4th. Rochester: Lawyers Co-operative Publ Co, 1982: 12, 544-604.

1142 United States Code Sec. 2000 et seq.

1229 United States Code Sec. 621 et seq.

1342 United States Code Sec. 12101 et sea

14 Rothstein M. Refusing to employ smokers: Good public health or bad public policy? Notre Dame Law Review 1987; 62: 940-68.

15 Garner D. Fair treatment for the new minority. Seton Hall Law Review. In press.

16 McManimon F. Employees who smoke have a right to privacy. HR Focus 1991; 68: 10 .

17 Scheg K. Smokers' "rights" laws threaten nonsmoking movement. Paper presented at the Eighth World Conference on Tobacco or Health, Buenos Aires, Argentina, 1-5 April 1992

18 Mayo v. US, 319 US 441 (1943).

19 Wells Inc. v. Shoemake, 177 P.2d 451 (Nev. 1947)

20 Lawyers Co-operative Publ Co. American furisprudence $2 d$. Vol. 41. Independent Contractors. Rochester: Lawyers Co-operative Publ Co., 1968.

21 Lawyers Co-operative Publ Co. American furisprudence $2 d$. Vol. 22. Damages, Sec 498. Rochester: Lawyers Cooperative Publ Co., 1988.

22 Lawyers Co-operative Publ Co. American furisprudence $2 d$.
Vol. 42. Injunctions. Rochester: Lawyers Co-operative Publ Co., 1968.

23 Hewitt v. Magic City Furniture \& Manf. Co., 107 So. 745 (Ala. 1926), 44 A.L.R. 1441

24 Lawyers Co-operative Publ Co. American furisprudence $2 d$. Vol. 22. Damages, Sec. 727. Rochester: Lawyers Cooperative Publ Co., 1988

25 People v. Latsis, 578 P.2d 1055, 1057 (Colo. 1978)

26 Jovanovic T. Age as bona fide occupational qualification "reasonably necessary" for normal conduct of business under Sec. 4(f) (1) of Age Discrimination in Employment Act. American Law Reports Federal. Rochester : Lawyers Co-operative Publ Co., 1983: 63: 610-623.

27 Grusendorf v. Oklahoma City, 816 F.2d 539 (10th Cir. 1987).

28 MacDonald v. Michigan, 911 F.2d 733 (6th Cir. 1990)

29 Graff v. Thermal Control, Inc., 2nd Judicial District for New Mexico, No. CV-90-13351 (1991).

30 Kurtz v. City of North Miami, Circuit Court of the 11th Judicial District in Dade County, FL, No. 91-3165 (04).

3129 USC 1001 et seq.

32946 F.2d 401 (1991), cert. denied (91-1283) 61 US Law Week 3355 (Nov. 11, 1992).

33 Goh, J. "Smokers need not apply": Challenging employment discrimination against smokers under the Americans with Disabilities Act. Univ Kansas Law Review 1991; 39: 817-43

34 American Psychiatric Association. Diagnostic and Statistical Manual III-R. American Psychiatric Association, 1987.

35 Malouff J, Schutte N, Kenyon A. Negative social effect of being a smoker. F Drug Educ 1991; 21: 293-302.

36 US v. Cooper Corp., 312 US 600 (1940)

37 US Department of Health and Human Services. Reducing the health consequences of smoking: 25 years of progress. Atlanta, GA: Centers for Disease Control, Office on Smoking \& Health 1989. (DHHS Publ No 89-8411.)

38 Daniels v. DCA, Inc., No. E16971-PADP5-4S, MN Dep Human Rights (1988).

39 Lipson v. Fortunoff Fine Jewelry \& Silverware, Inc., No. 2 E-D-84-99582, NY Executive Dept, State Division of Human Rights (1991).

Human Rights (1991).

41 NY Executive Law Sec. 296 et seq.

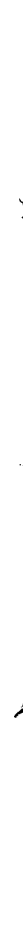

